\title{
Application of an Image Processing Technique for Early Diagnosis and Monitoring of Glaucoma
}

\author{
M. Taufiq Dardjat
}

\begin{abstract}
Abstrak
Percobaan ini dimaksudkan untuk mendeteksi dini kelainan glaukoma. Citra berwarna hasil pemotretan fundus okuli penderita glaukoma yang merupakan penyebab kebutaan dan menunjukan kelainan gambaran dijadikan sampel. Dengan pemanfaatan teknologi pengolahan citra berupa proyeksi radial dilakukan analisis citra tersebut. Metoda ini tergantung pada fakta bahwa area defek mempunyai refleksi yang lebih rendah pada panjang gelombang hijau dan biru dibanding area normal. Nilai intensitas refleksi Pixel (picture element) yaitu element terkecil dari gambar/warna di skor mulai 0 sampai 255. Perbedaan refleksi pixel itu sangat kecil pada kasus glaukoma dini. Metoda ini terdiri dari sampling dan sumasi (penjumlahan data) nilai-nilai pixel untuk warna biru dan hijau sepanjang garis radial antara dua lingkaran yang berpusat pada cup. Citra yang dipergunakan pada penelitian ini berupa foto fundus okuler berwarna yang didijitalisasi. Dari eksperimen ini dapat disimpulkan bahwa metoda ini dapat mendeteksi kelainan fundus yang relatif kecil dan dini yang biasanya hanya dapat ditemukan oleh ahli mata yang cukup berpengalaman. Metoda ini juga dapat dikatakan lebih baik dan praktis dibanding tenik enhansmen karena tidak membutuhkan iluminasi kompensasi, selain karena dapat mendeteksi cup secara otomatis. Penelitian ini perlu dilanjutkan ke tahap aplikasi langsung, sehingga hasil penelitian semakin dekat pada pemanfaatan teknologi cangih untuk bidang kesehatan mata, khususnya kelainan pada retina seperti glaukoma.
\end{abstract}

\begin{abstract}
Early stage glaucoma can be diagnosed by finding retinal nerve fiber defects using a color image processing technique. This method is based on the reflectance of the defective part which has low values in the green and blue wavelengths. The level pixel (picture element) of reflectance is scored from 0 to 255. In early stage glaucoma, the difference of that reflectance is very small. This new method detects that small difference. The method consists of sampling and summation value of pixels in green and blue along the radial lines drawn between two circles whose centers are the same and located at the center of the eye. It was found that the small differences can be detected only by doctors with a sufficient experience. This method is better than the color enhancement. Also, the detection of cup and blood vessels has been shown to assist in automatic processing. It will be necessary to apply this method to many patients to check the of the utility of the method and develop automatic processing system in the future.
\end{abstract}

Keywords : Image Processing, glaucoma, early diagnosis

\section{INTRODUCTION}

The result of eye morbidity survey conducted by Research and Development Institution, Ministry of Health, Republic of Indonesia in 1982 showed that the prevalence of blindness in Indonesia is about $1.2 \%$. There are about 2 million blindness cases in Indonesia among the population of 180 million (1991). Since blindness is not only a health problem, but also a social problem, the Indonesian Minister of Health stated in the official document No.19/Birhup/67 that blindness is a national "disaster". Blindness, or even vision loss before total blindness occurs, causes reductions in working hours, working capacity and working opportunity. Blindness causes reduction in productivity, which may be equal to billions rupiah per year. One of the important causes of blindness in Indonesia is glaucoma. ${ }^{10}$

Glaucoma occurs when the inner pressure of the eye ball increases. In the early stage of glaucoma, some clinical signs can be seen around the optic nerve head and in the retinal nerve fiber layer. The changes in the cup-disc ratio, the change of height in the rim of cup and optic nerve head pallor occurs around the optic nerve head because of the increased pressure. To measure these phenomenon automatically, three 
dimensional measurement method by using a grate projection on the retina ${ }^{1,2}$ has been proposed and tried. But this procedure takes a great time to search the corresponding points in the stereo-pair images. In the retinal nerve fiber layer, it appears that retinal nerve fiber axons are lost, but the patient still can see in all areas. The visual field defect can not be detected.

A small change of retinal reflectance in the blue and green wavelengths occurs because of loss of fibers. Also, a small change in height occurs. Several methods have been reported to evaluate the retinal nerve fiber layer. Hoyt and colleagues used red-free ophthalmoscopy and reported the significance of finding narrow, slit-like defects and large wedge-shaped defects in the retinal nerve fiber layer. ${ }^{3}$ Retinal photography has been used ${ }^{4,5}$ and computer enhancement of the retinal photographs has been tried. ${ }^{6,7}$ But it is difficult to detect small differences by these method.

In a recent study was reported a new method that is based on the assumption that the nerve fiber layer has birefringent properties, 8,9 and the fiber layer thickness has linear relation retardation (the polarization change) measured by Fourier-ellipsometry. This method gives us the value of point by point.

Here we propose a new method to detect the small difference by using sampling according to radial lines on a color retinal photograph and summation of these data. We also report the experimental results using color retinal photographs of normal and glaucoma eyes.

\section{METHODS}

The method consists of cup detection, radial projection, and blood vessel detection. The cup detection is used for deciding the center of the circles for the following processing. The radial projection is the main method for detecting the retinal nerve fiber defects. Blood vessel detection is used to classify the vessels and the retinal nerve fiber defect.

\section{Radial Projection}

The difference between defective part and normal parts of retinal nerve fiber layer is detected as the difference of density in blue and green images of color retina photographs. The quantity of the density difference is very small in the early stage of glaucoma. Here, a new method is proposed to detect this small difference. The ideal method consists of sampling the density data according to each nerve fiber bundle as shown in Figure 1, summation and comparing the summed data for each nerve fiber bundle. By this method, small difference is enlarged and can be seen as big dif- ference. Even if noise is added in images, noise is averaged and has no effect in the final summed data.

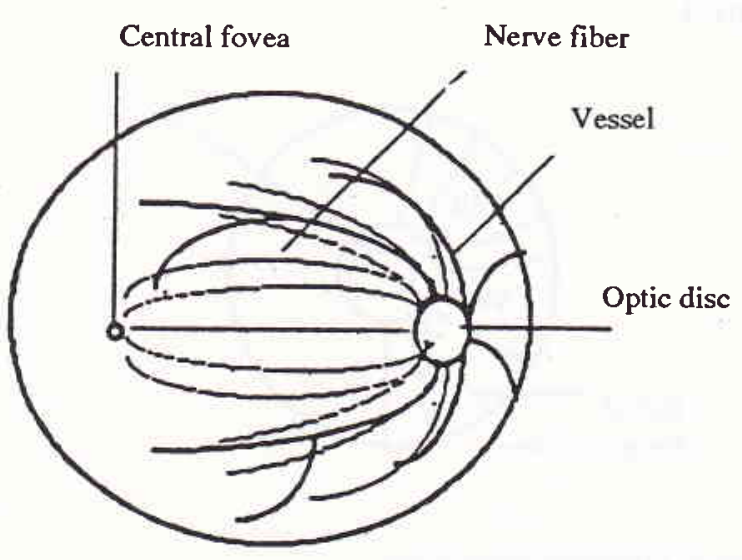

Figure 1. Projection along retinal nerve fiber axion

But it is not so clear where each fiber bundle runs. It is clear that each fiber bundle starts radial from the rim of the cup. So, the real method proposed here uses the radial sampling around the cup as shown in Figure 2 . It may called the radial projection method. In the computational method, two circles whose centers are the same and are in the cup are drown outside of the cup. Many radial lines are drown from the small circle to the large circle. The data is sampled according to each radial line.

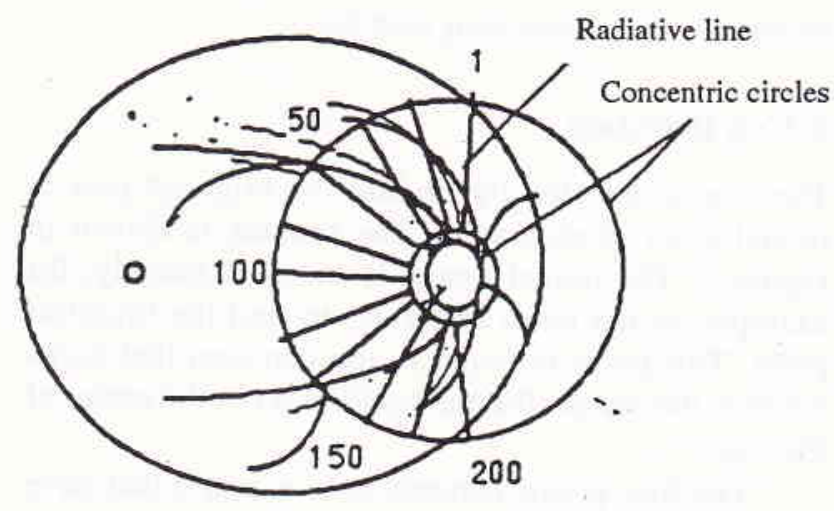

Figure 2. Radial projection around a cup. 
The method is explained using Figure 3. Sampling according to the straight lines in the area with the pixel value of sector 100 and 99 are shown in Figure 3. And the value of summation of data is shown in Figure 4.

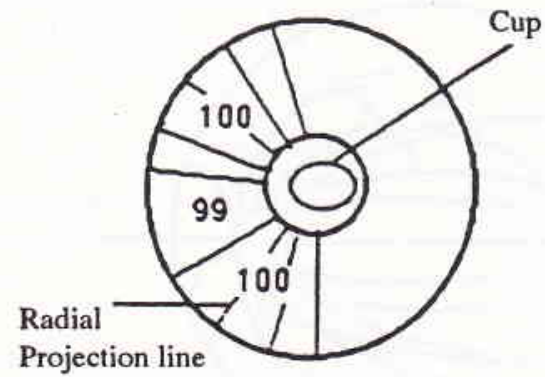

Figure 3. Projection along a line

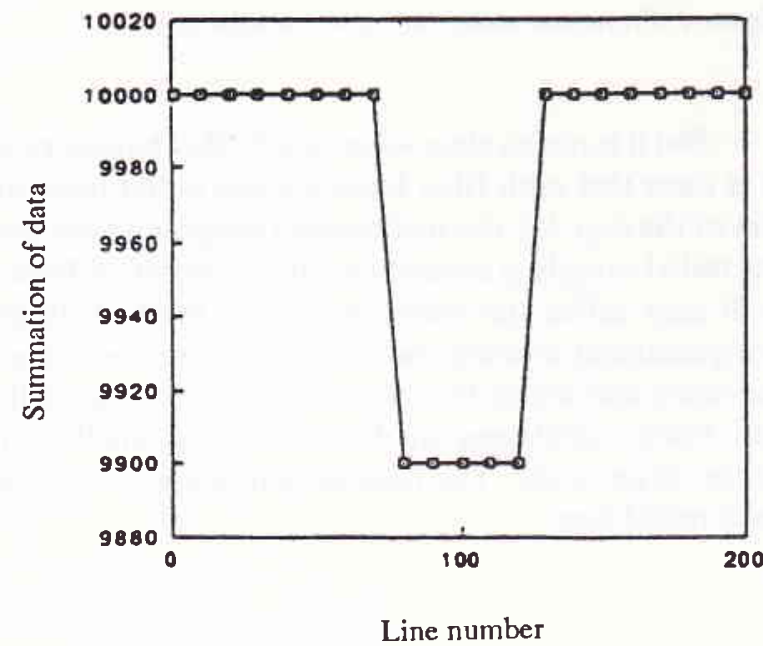

Figure 4. Projected data along each line

\section{Cup Detection}

The cup is detected by finding the brightest part in retinal color photographs. The process is shown in Figure 5. The retinal image is sampled roughly, for example, in ten point intervals to find the brightest point. This point is found in the cup area that looks white in the image. But the position is not the center of the cup.

The four points denoted $a, b, c$, and $d$ that have large variation in intensity are searched along horizontal and vertical lines drawn from the brightest point $\mathrm{A}$ shown in Figure 5. The center of the first circle shown as $C$ is decided by using the 4 points. The first circle is drawn a little bit outside the 4 points. The radius of second large circle is determined by the position of the cup and the image periphery. If the position of the cup is the upper left side shown in Figure 5, the radius of the second circle shown as $\mathrm{R} 2$ is the distance between the center of the cup and the periphery of the image.

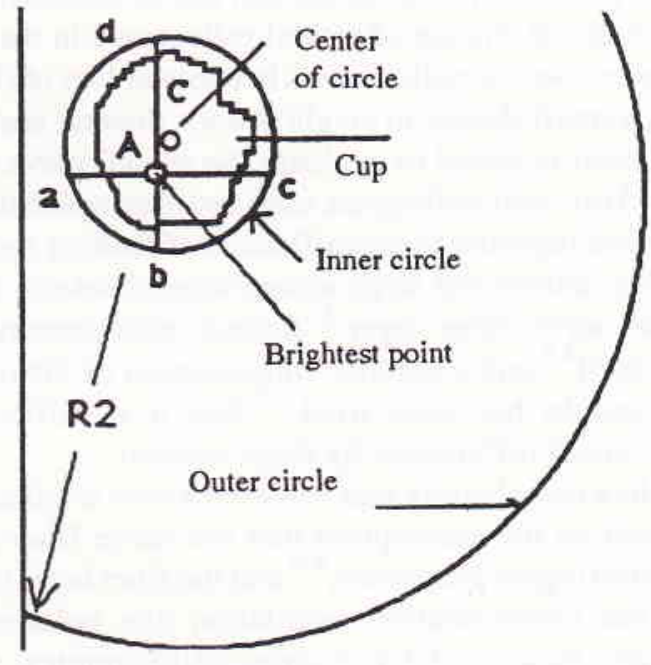

Figure 5. The method for automatic detection of the cup. The retinal image is resampled roughly to find the brightest point $A$. The four point $a, b, c$, and $d$ have large variation of the intensity. $C$ is the center of the first circle. $R 2$ is the radius of the second circle.

\section{Blood Vessel Detection}

The blood vessels look red and have lower intensity in green and blue wavelength on images as they run from the cup. Previous methods classify the blood vessels in colored spaces, and are only useful when the retina is uniformly illuminated. ${ }^{1,6,7}$ By this projection and sampling method, the uniformly illuminated photographs are unnecessary because each pixel (picture element) value of image will be averaged and noises on photograph will be losed

The new-method that uses around the cup in a green image is shown in Fig.6a and is plotted on a graph in Figure 6b. In Figure 6b, the blood vessel is detected as the dark part or lower value pixel in green or blue wavelength.

Finally, in the figures of radial projection (Figures 7-11) the defective part can be detected as the part with lower value in the slow continues change of the summed value due to the lack of flatness in illumination. And also, the blood vessel parts can be detected as the part with sharp decreasing in the same figure. But there two parts are clearly classified by using the information of blood vessel detection. 

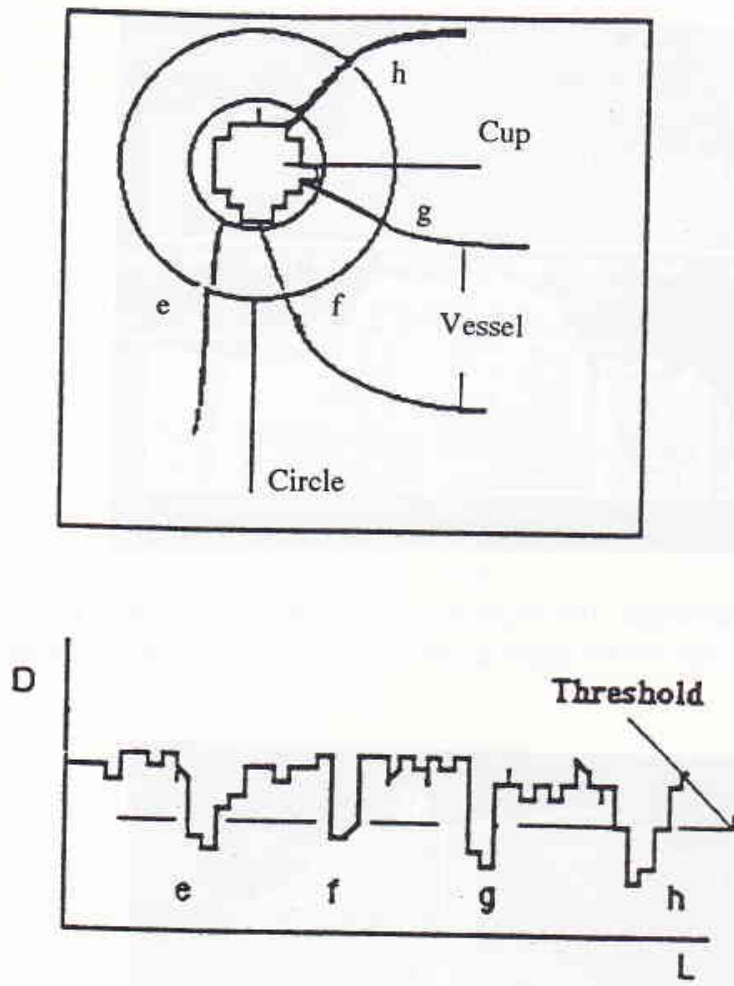

Figure 6. Blood vessel parts extracted by the method of circle resampling. (a) shows the resampling along the circle. (b) shows the result of resampling and classification using threshold.

\section{RESULTS}

Color photographics of retina nerve fiber of glaucoma eyes were used for this experiment. These color photographics were separated into red, green, and blue images with quantity level of 1 to 255 by using a scanner with the aperture of $100 \times 100$ micrometer. The green and the blue images were processed by using personal computer NEC98-01 with image buffer and C-Language. Concentric circles are drawn automatically after detecting the center of the cup and the image periphery. Also, the radial lines were automatically drawn. The data is projected along each radial line. The processing time was about 10 seconds.

In Figure 7 to Figure 11, (a) shows the projection lines on the retina images and (b) shows the summed data on each line. In the Figure 7a, the wedge shaped defect can be seen clearly in above and below the cup. In the Figure $7 \mathrm{~b}$, the upper graph shows the summation in blue and the lower graph shows the summation in green. From Figure $7 \mathrm{~b}$, we find that the values of summation from the line number of 0 to 140 and 300 to 370 are small. Of course, these two parts correspond with the defective part shown in Figure a. The sharp decreasing part painted red at the line number of 50 , 150 and 390 is due to the effect of blood vessels.

In Figure 8a, a wedge shaped defect is seen from the upper right side to the lower left side in the center. In Figure $8 \mathrm{~b}$, the line number of this defect is $\mathbf{2 0 0}$ to 270. This part looks like a mountain because the illumination was not flat. If the defect were not there, the shape would be a perfect hemisphere. In Figure 9a, it is difficult to find the defective part. At the line number of 100 , sharp decreases are seen because of blood vessels noted in the lower graph of Figure $9 \mathrm{~b}$. The defective part can not be found from the summed data in green. At the line number of 150 to 230 and 300 to 350 , summed data have low values in the upper graph. This part can be diagnosed as defective part by an experienced physician.

In the Figure 10a, two defective parts are detected. One is clearly observed at line number 100 to 150 in the retinal photograph and in the radial projection map shown in Figure 10b. The other is detected at line number 300 in the radial projection map, but it is difficult to find it in the retinal photography due to its small difference. This part is also detected as the low value at line number 250 in Figure 11b.

Through these experiments, it was found that small differences between nerve fiber defects and the normal parts can be detected, even if the illumination is not flat. If the defective part and the marked changes in blood vessels can be separated, the diagnosis will become easy.

\section{CONCLUSIONS}

The radial projection method is proposed to detect the nerve fiber defect in the early stage of glaucoma. The method depends on the fact that the defect has a lower reflectance compared to the normal part. The method consists of sampling and summation along radiating lines drawn between two circles whose centers are the same and located at the center of the cup of eye. Through experiments, it was found that the small difference of the defective and normal parts can be detected only by physicians with experience.

Sometimes, the problem in photography technique and processing is to make the homogen or flat illumination to the object. For these purpose we make compensation illumination. The bad or unflat illuminous will change intensity of the color, and finally will cause misdiagnosis. The compensation of illumination is needed to reduce the error in interpretation of photograph. Therefore this method does not need compensation of illumination. The detection of cup and blood vessels have been shown to assist the automatic processing. 


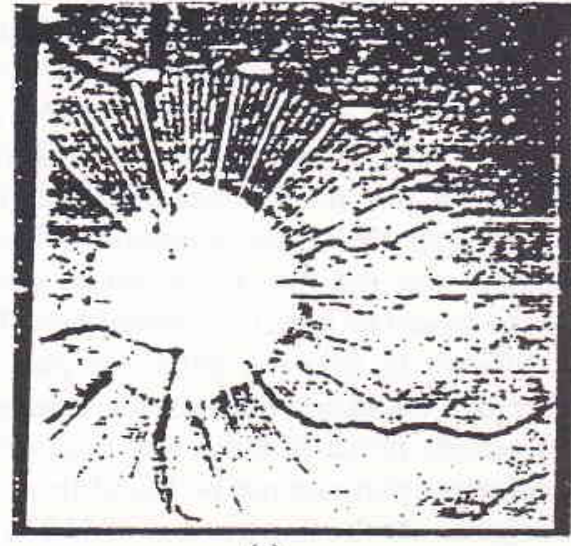

(a)

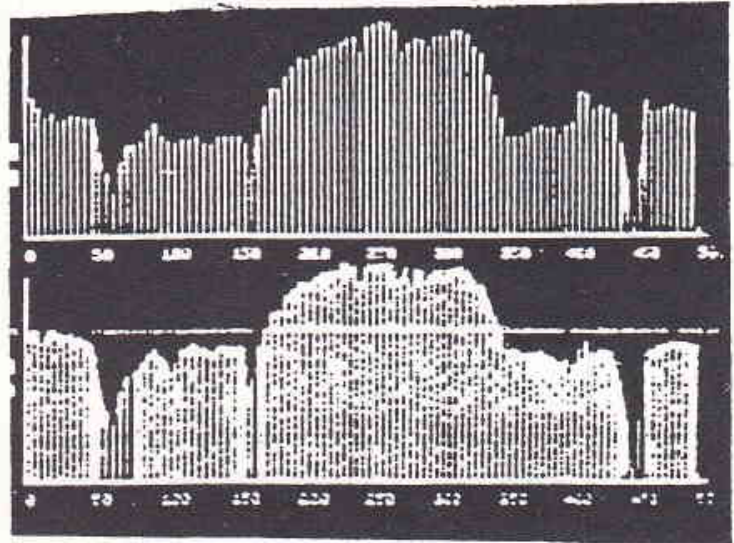

(b)

Figure 7. Experimental result. (a) shows the radial projection on the retinal image. The original image is color photograph. The wedge shaped defect is seen clearly in the up and down direction from the cup. (b) the upper graph shows the projection in blue and the lower graph shows the projection in green.

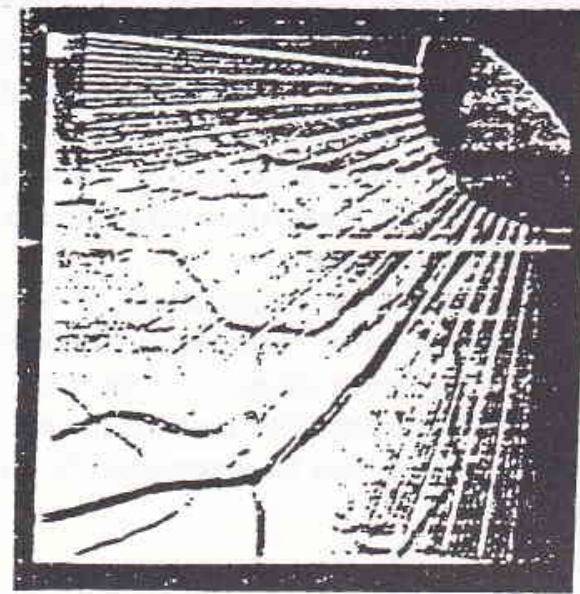

(a)

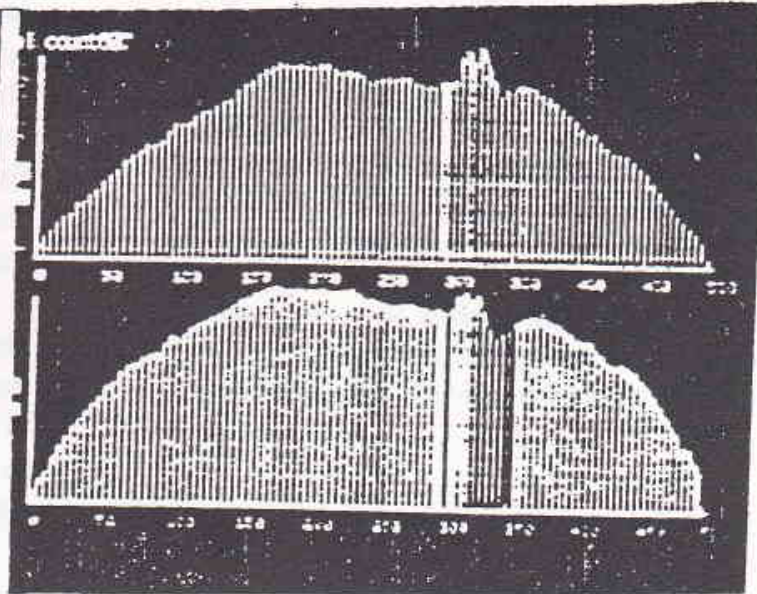

(b)

Figure 8. Experimental result. (a) shows the radial projection on the retinal image. The wedge shaped defect is seen from the upper right side to the lower left side in the center. (b) the upper graph shows the projection in blue and the lower graph shows the projection in green.
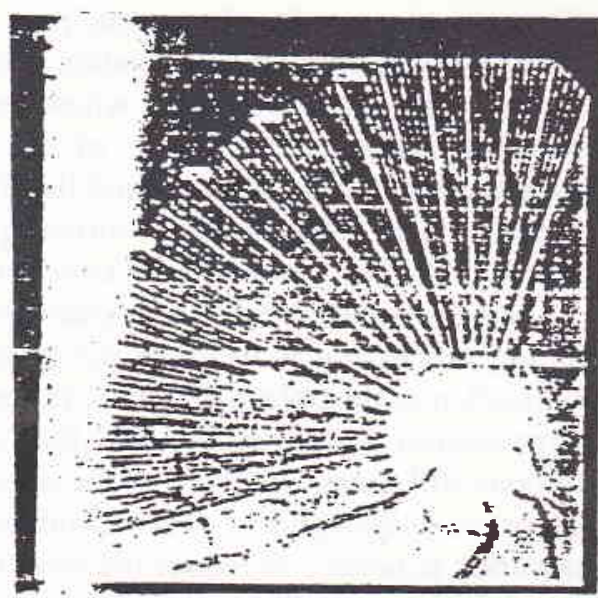

(a)

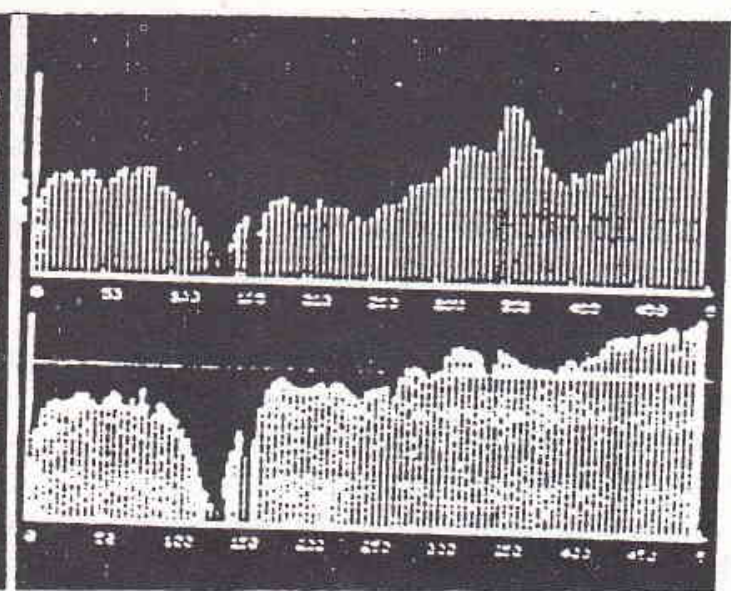

(b)

Figure 9. Experimental result. (a) shows the radial projection on the retinal image. This is the difficult example to find the defect part. (b) the upper graph shows the projection in blue and the lower graph shows the projection in green. 


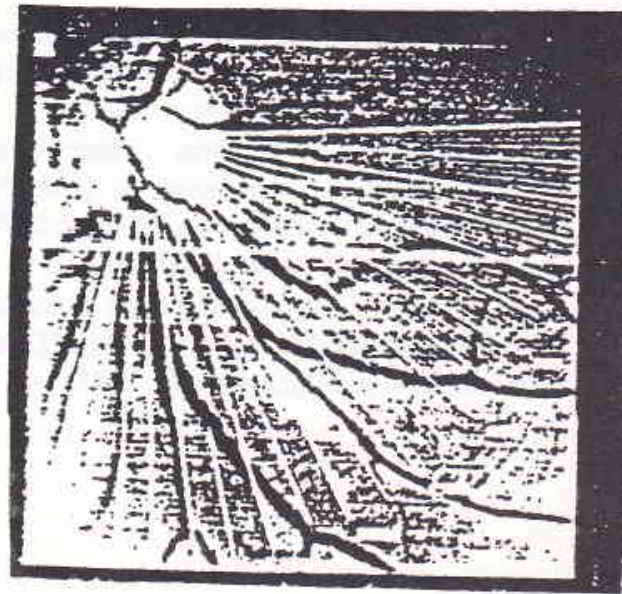

(a)

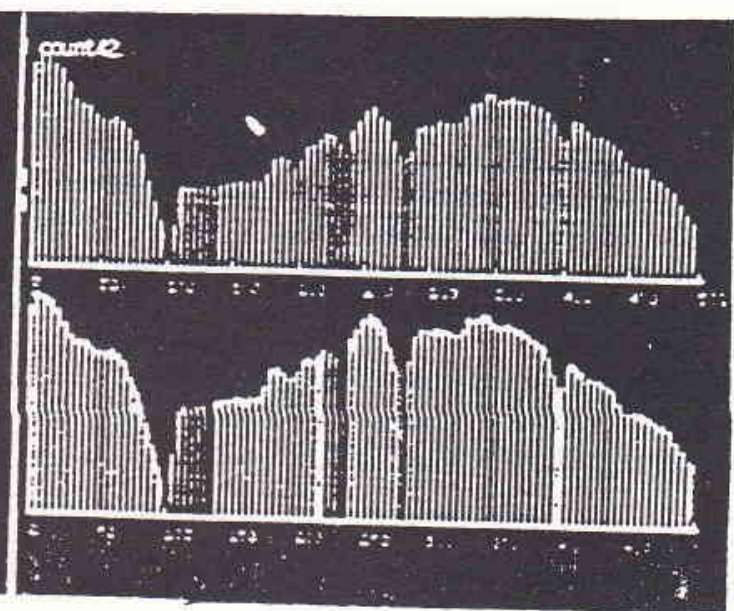

(b)

Figure 10. Experimental result. (a) shows the radial projection on the retinal image. (b) the upper graph shows the projection in blue and the lower graph shows the projection in green.

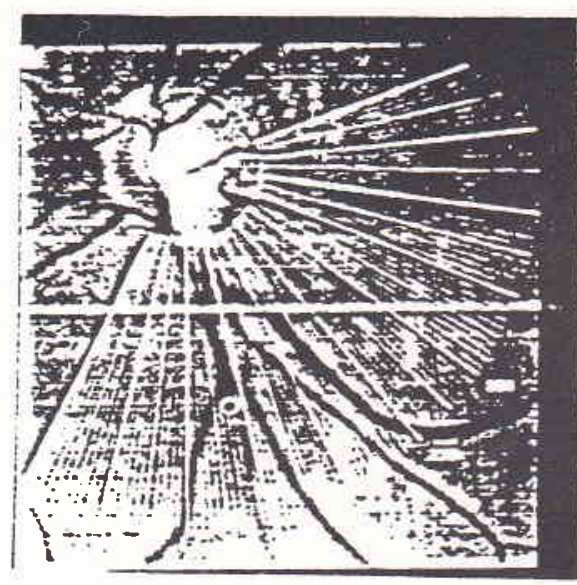

(a)

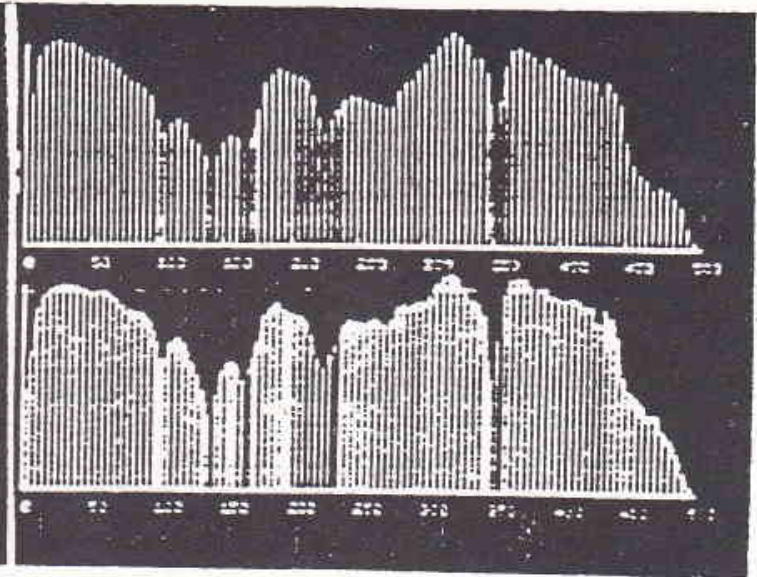

(b)

Figure 11. Experimental result. (a) shows the radial projection on the retinal image. (b) the upper graph shows the projection in blue and the lower graph shows the projection in green.

As it is mentioned before, the scanner was used in this experiment to replace the video-camera, due to the budget limitation. This limited the application of this method to the patients. We will apply this method to many patients to check the usefulness of the method and we will develop full automatic processing in the future. Advanced research and experiments are needed to apply and develop the method.

\section{Acknowledgements}

I especially appreciate and acknowledge the useful guidance and advice from Prof. Y. Yasuda, my academic advisor during my period of study of the image processing technique at Chiba University, Japan. I also acknowledge my special thank to Asso.
Prof. K. Ohnuma who gave me important assistance during the conducting of this research.

\section{REFERENCES}

1. Cornsweet TN, Hersh S, Humpries JC, Beesmer RJ, Cornsweet DW editors. Quantification of the Shape and Color of the Optic Nerve Head Proceeding of the Second International Symposium; 1982; October 23-5:Tucson Arizona, Spring Verlag, 1983.

2. Yoshimura T, Fujita Y, Nakaya H, Suzuki N. Development of Three Dimensionally Measuring Instrument of Ocular Fundus in Kogaku. Japan Journal of Optics 1973;18:495501.

3. Hoyt WF, Frisen L, Newman NM. Funduscopy of Nerve Fiber Layer Defects in Glaucoma Invest Ophtalmology 1984;12:814-29. 
4. Sommer A, Quigley HA, Robin AL, Miller NR, Katz J, Arkell S. Evaluation of Nerve Fiber Layer Assessment in Arch Ophthalmology 1984;98:566-71.

5. Airaksinen PJ, Drance SM, Douglas GR, Mawson DK, Nieminen H. Diffuse and Localized Nerve Fiber Loss in Glaucoma. Am J Ophthalmol 1984;98:566-71.

6. Peli E, Hedges TR, Schwarts B. Computerized Enhancement of Retinal Nerve Fiber Layer. Acta Ophthalmologica 1986;64:113-22.

7. Cooper RL, Eikelboom RH, Barry C. Computerized Densitometry of Red-free Retinal Photographs Correlated with Automated Perimetry. Curr Eye Res 1988;7:789-92.
8. Brink HB, Van Blokland GJ. Birefringence of the Human Foveal Area Assessed in Vivo with Mueller-matrix Ellipsometry. J Opt Soc Am 1989; A.5:49-57.

9. White RN, Andreas WD, Anne C, Harry Q, Blake S, Klaus R. Histopathologic Validation of Fourier-Ellipsometry Measurements of Retinal Nerve Fiber Layer Thickness. Arch Ophthalmology 1990; 108:577-5600.

10. Buku Pedoman Kesehatan Mata dan Pencegahan Kebutaan untuk PUSKESMAS. Ditjen Pembinaan Kesehatan Masyarakat, Departemen Kesehatan RI, 1985, 7-11. 